\title{
Prevalence of byssinosis in Swedish cotton mills
}

\author{
P HAGLIND, MONICA LUNDHOLM, AND R RYLANDER \\ From the Department of Environmental Hygiene, University of Gothenburg, Gothenburg, Sweden
}

\begin{abstract}
The prevalence of byssinosis and of chronic bronchitis was studied in a questionnaire investigation among workers in bale opening areas, carding rooms, and spinning rooms in five Swedish cotton mills. Airborne dust and Gram-negative bacteria were measured. Nineteen per cent of the interviewed workers reported symptoms of light byssinosis (grade 1/2). The prevalence of symptoms was not related to the duration of employment, and cases of byssinosis were found among people who had worked in cotton mills for only a few years. A significantly higher proportion of male than female workers reported symptoms. No difference in the extent of byssinosis was found between smokers and non-smokers, but the prevalence was significantly higher among those workers who had ceased smoking. The prevalence of byssinosis was related to the number of airborne viable Gram-negative bacteria as well as to the dust level in the different mills.
\end{abstract}

The presence of byssinosis among workers in cotton mills has been well documented in studies from several countries. ${ }^{1}$ The development of the disease has been related to the dust level, ${ }^{2} 3$ but several observations suggest that the bacterial contamination of cotton is important. ${ }^{4-7}$ Other studies have shown that smoking and duration of employment influence the prevalence of byssinotic symptoms among exposed workers. ${ }^{2} 38$ In a previous investigation in Sweden $^{9} 117$ employees in four cotton mills were examined, and the extent of byssinosis ranged from $25 \%$ to $68 \%$. No relation could be found between dust levels and byssinosis.

We undertook this study to determine the prevalence of byssinosis among workers in different cotton mills in Sweden and to relate the proportion of workers reporting symptoms to dust levels and the number of airborne aerobic Gram-negative bacteria

\section{Materials and methods}

The investigation was conducted in all five cotton mills operating in Sweden in 1977. A register of the employees working in bale opening, carding, and spinning areas was obtained from the personnel department at each mill. In one mill an area was included where cleaned cotton was carded to produce a high quality medical cotton. The employees were

Received 2 January 1980

Accepted 8 February 1980 interviewed using a questionnaire based on the British Medical Research Council questionnaire for byssinosis. This contained questions related to chest tightness and airway symptoms appearing on particular days during the workweek. Questions were also asked on smoking habits, duration of employment in the mill, and the presence of pulmonary symptoms and disease. Each industry was visited on several occasions in order to reach all the employees. Interviews were usually performed by a physician (PH) but occasionally by the occupational health nurse.

Employees reporting chest tightness on Mondays or after return from vacation or leave and those reporting other respiratory symptoms in the airways on Mondays, such as cough, irritation, tightness in the throat, or breathing difficulties, were classified as byssinotics. Employees who had had a cough with phlegm for more than three years and periods of coughing lasting longer than three months within a one-year period were classified as having chronic bronchitis.

The smokers were divided into those smoking $1-5,6-14$, and 15 or more cigarettes a day. The few pipe smokers were classified so that a consumption of $50 \mathrm{~g}$ of pipe tobacco a week corresponded to 1-5 cigarettes a day. People who stated that they were non-smokers were divided into those who had smoked previously and those who had never smoked.

The dust levels in the different working areas were determined by filtering air through Millipore 
cellulose acetate filters (diameter $37 \mathrm{~mm}$, pore size $0.8 \mu \mathrm{m}$ ) supplied with a metal grid (mesh size $2 \mathrm{~mm}$ ) to exclude larger fibres. The air flow was $12 \mathrm{l} / \mathrm{min}$, and the sampling time 180-300 minutes. Determinations were made on at least two different days at the various working areas in the mills. A limited number of determinations of the particle size distribution in the airborne dust was made in areas for carding and spinning using a Royco particle size analyser (model 225).

The number of airborne aerobic Gram-negative rods was determined with an Andersen sampler ${ }^{10}$ using Drigalski agar as a selective medium. Two or three samples were taken at different times of the day on two days, at two different sites in each working area. After incubation at $35^{\circ} \mathrm{C}$ for 40 hours, the number of colonies was counted and corrected as recommended by Andersen. The results were expressed as thousands of colony forming units $\left(\mathrm{cfu} \times 10^{3}\right)$ per cubic metre of air. Samples of bale cotton and carded cotton from three different mills were analysed for Gram-negative bacteria. One gram of the material was suspended in $10 \mathrm{ml}$ of $0.9 \% \mathrm{NaCl}$ and shaken vigorously. The fluid was squeezed out of the cotton which was then replaced in the same liquid. After repeating this procedure five times serial dilutions were prepared from the fluid, and a $0.1 \mathrm{ml}$ sample was inoculated on to Drigalski agar plates. The number of colonies was counted after incubation at $35^{\circ} \mathrm{C}$ for 40 hours. The bacterial species present were identified from a sample of the Drigalski agar plates from each mill. The strains were selected by morphological appearance and further tested on seni-solid oxidative fermentative (O-F) medium. ${ }^{11}$ The tests were incubated at $35^{\circ} \mathrm{C}$ for two days and observed daily. Fermentative strains were identified by the API microtube $20 \mathrm{E}$ profile system (Analytab Products, Plainview, NY). Non-fermentative strains were identified using different biochemical tests and, in some cases, immunological methods (E Falsen, unpublished observations).

The dust, bacteria, and particle sizes were measured during the same six-month period in which the interviews took place.

\section{STATISTICAL PROCEDURES}

The differences between various observations in groups of employees were tested for statistical significance using the Fisher permutation test with a pooling procedure ${ }^{12}$ that tests the relation between two observations with a third as a constant factor. To analyse the effect of duration of employment on the prevalence of symptoms, the employees were divided into five age-groups. The correlation between duration of employment and prevalence was calculated for each group, and these correlations were used in a pooling procedure in which age was the constant factor. Chi-square testing for trends in contingency tables was also used. The $p$ values quoted are those that apply to two-tailed tests.

\section{Results}

INTER VIEW INVESTIGATION

Out of 289 employees working in bale opening, carding, and spinning areas, 248 were interviewed. The drop-out $(14 \%)$ consisted of those on sick leave or those who had left work during the period of the investigation. Only four employees refused to participate. Those who dropped out did not differ significantly from those interviewed in distribution of age or duration of employment. The numbers of men and women interviewed were about equal, and age was fairly uniformly distributed. More than half of the workers had been employed less than 10 years.

\section{EXPOSURE AND BYSSINOSIS}

The number of particles in carding areas was more than twice the number in spinning areas (table 1).

Table 1 Number of particles/ml air and size distribution of particles in carding room and spinning areas. Average from two measurements in four mills \pm standard deviation (total deviates from $100 \%$ due to approximations)

\begin{tabular}{lrr}
\hline & Carding & Spinning \\
\hline $\begin{array}{l}\text { No of particles } \\
\text { Percentage size distribution } \\
(\mu \mathrm{m})\end{array}$ & $258 \pm 85$ & $100 \pm 22$ \\
$\mathbf{0} \cdot 5-0 \cdot 7$ & & \\
$\mathbf{0} \cdot 8-1 \cdot 4$ & $70 \pm 4$ & $84 \pm 3$ \\
$1 \cdot 5-3 \cdot 0$ & $17 \pm 3$ & $9 \pm 2$ \\
$3 \cdot 1-5 \cdot 0$ & $10 \pm 2$ & $6 \pm 2$ \\
$>5 \cdot 0$ & $1 \pm 1$ & $1 \pm 0 \cdot 2$ \\
\hline
\end{tabular}

The size of most particles in the carding and spinning areas was $0 \cdot 5-0 \cdot 7 \mu \mathrm{m}$. The size distribution tended to shift towards smaller particles in the spinning area.

Between $47 \%$ and $93 \%$ of viable airborne Gramnegative bacteria were Enterobacter agglomerans. Pseudomonas syringae was also often found (4-21\%) (table 2). Agrobacterium species were found in small numbers (less than $2 \%$ ), as was Klebsiella pneumoniae and oxytoca and Ent cloacae. In addition Acinetobacter calcoaceticus, Pseudomonas maltophilia, and Ps fluorescens were occasionally found, together with a few unidentified bacteria. The different sampling areas within each mill had similar percentages of the different species-for 
Table 2 Percentage of different species of Gram-negative rods in air samples from bale opening areas, carding rooms, spinning areas, and medical cotton area

\begin{tabular}{|c|c|c|c|c|c|c|c|}
\hline Mill & Site & $N$ & Ent agglom & Ps syringae & Agrobacterium & Klebsiella/Ent cloacae & Miscellaneous \\
\hline $\mathbf{A}$ & $\begin{array}{l}\text { Bale } \\
\text { Card } \\
\text { Spinning }\end{array}$ & $\begin{array}{l}18 \\
12 \\
15\end{array}$ & $\begin{array}{l}70 \\
68 \\
74\end{array}$ & $\begin{array}{l}17 \\
21 \\
14\end{array}$ & $\begin{array}{l}1 \cdot 5 \\
0 \cdot 2 \\
0 \cdot 3\end{array}$ & $\begin{array}{l}2 \\
2 \\
3\end{array}$ & $\begin{array}{r}10 \\
9 \\
9\end{array}$ \\
\hline B & $\begin{array}{l}\text { Bale } \\
\text { Card } \\
\text { Spinning }\end{array}$ & $\begin{array}{l}15 \\
15 \\
18\end{array}$ & $\begin{array}{l}93 \\
92 \\
92\end{array}$ & $\begin{array}{l}6 \\
6 \\
6\end{array}$ & $\begin{array}{l}0 \cdot 2 \\
0 \cdot 2 \\
0 \cdot 3\end{array}$ & $\begin{array}{l}0 \\
0 \\
0\end{array}$ & $\begin{array}{l}1 \\
2 \\
1\end{array}$ \\
\hline C & $\begin{array}{l}\text { Bale } \\
\text { Card } \\
\text { Spinning }\end{array}$ & $\begin{array}{l}12 \\
15 \\
19\end{array}$ & $\begin{array}{l}87 \\
83 \\
89\end{array}$ & $\begin{array}{l}4 \\
4 \\
5\end{array}$ & $\begin{array}{l}0 \cdot 2 \\
0 \cdot 3 \\
0 \cdot 5\end{array}$ & $\begin{array}{l}3 \\
3 \\
3\end{array}$ & $\begin{array}{r}6 \\
10 \\
3\end{array}$ \\
\hline D & $\begin{array}{l}\text { Bale } \\
\text { Card } \\
\text { Spinning }\end{array}$ & $\begin{array}{l}10 \\
16 \\
15\end{array}$ & $\begin{array}{l}76 \\
79 \\
73\end{array}$ & $\begin{array}{l}15 \\
15 \\
15\end{array}$ & $\begin{array}{l}0 \cdot 3 \\
0 \cdot 2 \\
0 \cdot 3\end{array}$ & $\begin{array}{l}2 \\
2 \\
2\end{array}$ & $\begin{array}{r}7 \\
4 \\
10\end{array}$ \\
\hline $\mathrm{E}$ & $\begin{array}{l}\text { Bale } \\
\text { Card } \\
\text { Spinning }\end{array}$ & $\begin{array}{l}15 \\
14 \\
15\end{array}$ & $\begin{array}{l}47 \\
49 \\
50\end{array}$ & $\begin{array}{l}21 \\
20 \\
21\end{array}$ & $\begin{array}{l}0.5 \\
0.4 \\
0.5\end{array}$ & $\begin{array}{l}1 \\
1 \\
1\end{array}$ & $\begin{array}{l}31 \\
30 \\
27\end{array}$ \\
\hline $\mathbf{M}$ & Carding & 7 & 81 & 19 & & & \\
\hline
\end{tabular}

$\mathrm{N}=$ No of measurements.

instance, mill B with $50 \%$ Ent agglomerans and $20 \%$ Ps syringae in all areas, while mill D had over $90 \%$ Ent agglomerans and $6 \%$ Ps syringae. The samples of bale and carded cotton from three of the mills contained varying numbers of Ent agglomerans (17-99\%) and Ps syringae (3-69\%) (table 3). The total content of Gram-negative rods varied between $10^{2} \mathrm{cfu} / \mathrm{g}$ and $10^{8} \mathrm{cfu} / \mathrm{g}$ cotton.

Table 4 reports exposure conditions and byssinosis for different working sites at the five mills. In all mills the dust levels were lower and the number of cfu of Gram-negative bacteria were strikingly lower in the spinning areas than in the carding rooms. The number of cfu and the dust levels were closely related $\left(r_{x y}=0.67\right)$, but the ratio between airborne

Table 3 Determinations of bacterial content of bale cotton and carded cotton from three different mills and species of Gram-negative rods in percentage of total count

\begin{tabular}{lllllll}
\hline Mill & $\begin{array}{l}\text { Origin of } \\
\text { cotton sample }\end{array}$ & $\begin{array}{l}\text { Total } \\
\text { cfu/g }\end{array}$ & $\begin{array}{l}\text { Ent } \\
\text { agglom } \\
(\%)\end{array}$ & $\begin{array}{l}\text { Ps } \\
\text { syringae } \\
(\%)\end{array}$ & $\begin{array}{l}\text { Klebsiella/Ent } \\
\text { cloacae } \\
(\%)\end{array}$ \\
\hline A & Peru & 1 & $10^{4}$ & 99 & & \\
& Turkey & 1 & $10^{4}$ & 17 & 69 & \\
& Russia & 1 & $10^{2}$ & 75 & 25 & \\
& California & 1 & $10^{5}$ & 53 & 42 & \\
& "Carded" & 3 & $10^{8}$ & 89 & 7 & $<1$ \\
D & Russia & 4 & $10^{5}$ & 94 & 4 & $<1$ \\
& Texas & 8 & $10^{7}$ & 93 & 6 & 1 \\
& "Carded" & 2 & $10^{5}$ & 95 & 3 & 2 \\
E & USA I & 2 & $10^{5}$ & 60 & 30 & 10 \\
& USA II & 2 & $10^{8}$ & 77 & 17 & 5 \\
& Russia & 2 & $10^{4}$ & 50 & & 12 \\
& "Carded" & 2 & $10^{7}$ & 85 & 4 & 12 \\
\hline
\end{tabular}

$\mathrm{N}=$ No of measurements.
Table 4 Dust levels and airborne Gram-negative bacteria, workers interviewed, and workers reporting symptoms of byssinosis in different mills. Mean and standard deviation from 2-6 determinations (dust), 11-40 determinations (bacteria)

\begin{tabular}{|c|c|c|c|c|c|c|}
\hline \multirow{2}{*}{$\begin{array}{l}\text { Mill } \\
\mathbf{A}\end{array}$} & \multicolumn{2}{|c|}{ Site $\mathrm{mg} / \mathrm{m}^{3}$} & $\begin{array}{l}c f u \text { (thousands) } \\
/ m^{3}\end{array}$ & \multirow{2}{*}{$\begin{array}{l}\text { Interviewed } \\
\text { No }\end{array}$} & \multicolumn{2}{|c|}{$\begin{array}{l}\text { Byssinosis } \\
\text { No \% }\end{array}$} \\
\hline & B & $0.3 \pm 0.1$ & $15 \pm 9$ & & 3 & 27 \\
\hline & $\mathrm{C}$ & $0.8 \pm 0.4$ & $60 \pm 29$ & 34 & 11 & 32 \\
\hline & $\mathbf{S}$ & $0.4 \pm 0.1$ & $10 \pm 5$ & 77 & 10 & 13 \\
\hline \multirow[t]{3}{*}{$\mathbf{B}$} & B & $1.6 \pm 0.1$ & $81 \pm 26$ & 3 & 1 & 33 \\
\hline & C & $2.0 \pm 0.4$ & $112 \pm 16$ & 6 & 4 & 67 \\
\hline & $\mathbf{S}$ & $1.3 \pm 0.4$ & $33 \pm 16$ & 26 & 10 & 38 \\
\hline \multirow[t]{3}{*}{ C } & B & NM & $35 \pm 12$ & 3 & 1 & 33 \\
\hline & $\mathrm{C}$ & $0.7 \pm 0.1$ & $56 \pm 16$ & 15 & 1 & 7 \\
\hline & $\mathbf{S}$ & $0.5 \pm 0.2$ & $10 \pm 4$ & 30 & 6 & 20 \\
\hline \multirow[t]{3}{*}{ D } & B & NM & $70 \pm 15$ & 0 & 0 & - \\
\hline & C & $0.7 \pm 0.2$ & $40 \pm 17$ & 5 & 0 & 0 \\
\hline & $\mathbf{S}$ & $0.5 \pm 0.2$ & $14 \pm 7$ & 18 & 1 & 6 \\
\hline \multirow[t]{3}{*}{$\mathbf{E}$} & B & $0.3 \pm 0.01$ & $11 \pm 4$ & 1 & 0 & 0 \\
\hline & $\mathrm{C}$ & $0.6 \pm 0.1$ & $22 \pm 10$ & 6 & 0 & 0 \\
\hline & $\mathbf{S}$ & $0.3+0.1$ & $5+2$ & 8 & 0 & 0 \\
\hline $\mathbf{M}$ & C & $1.6 \pm 0.8$ & $0.6 \pm 0.6$ & 5 & 0 & 0 \\
\hline
\end{tabular}

$\mathbf{B}=$ Bale opening; $\mathbf{C}=$ carding $\mathbf{S}=$ spinning $; \mathbf{M}=$ medical cotton $\mathrm{NM}=$ No measurements.

bacteria and dust level in the medical cotton working plant was very low.

The number of people reporting byssinotic symptoms in the different mills and at various working sites ranged from none among eight workers to four out of six. The percentage values given in table 5 should be treated with caution as some are based on a very low number of employees. Using the data from all working sites (table 4), the prevalence of byssinosis was shown to be significantly related to levels of both dust and bacteria (table 6). 
Table 5 Byssinosis and chronic bronchitis among men and women at different working sites

\begin{tabular}{llcrrrr}
\hline Working site & Sex & Interviewed & \multicolumn{3}{c}{ Byssinosis } & \multicolumn{2}{c}{ Chronic bronchitis } \\
& & & No & $\%$ & No & $\%$ \\
\hline Bale opening & F & 0 & 0 & - & 0 & - \\
Carding & M & 18 & 5 & 28 & 2 & 11 \\
\multirow{5}{*}{ Spinning } & F & 17 & 4 & 24 & 2 & 12 \\
& M & 49 & 12 & 25 & 4 & 8 \\
Medical cotton & F & 101 & 11 & 11 & 6 & 6 \\
\multirow{2}{*}{ All } & M & 58 & 16 & 28 & 5 & 9 \\
& M & 3 & 0 & 0 & 0 & 0 \\
& F & 121 & 0 & 0 & 0 & 0 \\
& M & 127 & 15 & 12 & 8 & 7 \\
& All & 248 & 33 & 26 & 11 & 9 \\
& & & 48 & 19 & 19 & 8 \\
\hline
\end{tabular}

$\mathrm{F}=$ Female, $\mathbf{M}=$ Male.

Table 6 Product moment correlation coefficients between the prevalence of byssinosis $(\%$ of workers reporting symptoms) and dust levels and colony forming units of airborne Gram-negative bacteria (data in table 4)

\begin{tabular}{lll}
\hline & All sites & $\begin{array}{l}\text { All sites except } \\
\text { medical cotton }\end{array}$ \\
\hline Dust & $0.62^{*}$ & $0.81 \ddagger$ \\
Colony forming units & $0.73 \dagger$ & $0.71 \S$ \\
\hline $0.05>\mathrm{p}>0.01 . \dagger 0.01>\mathrm{p}>0.001 . \ddagger \mathrm{p}<0.001 . \S 0.01>\mathrm{p}>0.001$.
\end{tabular}

BYSSINOSIS AND INDIVIDUAL

CHAR ACTERISTICS

In the five mills $19 \%$ of interviewed employees were found to have symptoms of byssinosis. The prevalence of byssinosis (table 5) was higher among men $(26 \%)$ than among women $(12 \%)(0.02>p>$ $0.01)$. This difference between the sexes could not be explained by different smoking habits. When the employees were divided according to working sites, the sex difference was statistically significant for spinning areas $(0.02>p>0.01)$ but not for carding areas. No significant difference was found in the prevalence of chronic bronchitis between men and women as a group, or between different working sites.

Among those interviewed the proportion with byssinosis (table 7) was related to the duration of employment $(0.01>p>0.001)$. With age as a

Table 7 Byssinosis and chronic bronchitis among workers with different durations of employment

\begin{tabular}{llrrrr}
\hline Employment $(y r)$ & $\begin{array}{l}\text { People } \\
\text { interviewed }\end{array}$ & \multicolumn{2}{c}{ Byssinosis } & \multicolumn{2}{c}{ Chronic bronchitis } \\
& & No & No & $\%$ \\
\hline$\leqslant 9$ & 134 & 17 & 13 & 9 & 7 \\
$10-19$ & 39 & 9 & 23 & 6 & 15 \\
$20-29$ & 23 & 10 & 43 & 1 & 4 \\
$30-39$ & 25 & 5 & 20 & 2 & 8 \\
$\geqslant 40$ & 27 & 7 & 26 & 1 & 4 \\
\hline
\end{tabular}

constant factor no significant correlation between duration of employment and prevalence of byssinosis was found. In each employment time interval the proportion of men with byssinosis was higher than the proportion of women. Using the same method of analysis no significant correlation was found between age and prevalence of byssinosis with duration of employment as a constant factor. The number of employees with chronic bronchitis was too small to show any significant correlation with age or duration of employment.

Table 8 Byssinosis and chronic bronchitis among smokers and non-smokers

\begin{tabular}{lrrrrr}
\hline & \multicolumn{3}{c}{ No interviewed } & \multicolumn{3}{c}{ Byssinosis } & \multicolumn{2}{c}{ Chronic bronchitis } \\
& & No & $\%$ & No & $\%$ \\
\hline Non-smokers & 131 & 24 & 18 & 8 & 6 \\
$\quad$ Never smoked & 96 & 13 & 14 & 5 & 5 \\
$\quad$ Ceased smoking & 35 & 11 & 31 & 3 & 9 \\
Smokers & 117 & 24 & 21 & 11 & 9 \\
Cigarettes/day & & & & & \\
1-5 & 21 & 4 & 19 & 0 & 0 \\
$6-14$ & 36 & 8 & 22 & 3 & 8 \\
$\geqslant 15$ & 60 & 12 & 20 & 8 & 13 \\
\hline
\end{tabular}

Table 8 shows the distribution of byssinosis and chronic bronchitis among non-smokers and smokers. Byssinosis was present in $18 \%$ of the non-smokers. A significantly higher proportion of those who had stopped smoking than of those who had never smoked reported byssinotic symptoms $(0.05>p$ $>0.02$ ). The prevalence of byssinosis was slightly higher among the smokers than among non-smokers, but the difference was not statistically significant. The prevalence of byssinosis was not related to the number of cigarettes a day or number of years that the worker had smoked.

Of the non-smokers, $6 \%$ had symptoms of chronic bronchitis. A slightly higher prevalence was found among the heavy smokers and a tendency to a doseresponse relationship could be observed.

A significantly larger proportion of workers with byssinosis were classified (table 9) as chronic bronchitics than were those without byssinosis $(19 \%$ and $5 \%$ respectively $0.01>p>0.001)$.

Table 9 Chronic bronchitis among interviewed with and without byssinosis

\begin{tabular}{lccc}
\hline Byssinosis & No interviewed & \multicolumn{2}{c}{ Chronic bronchitis } \\
& & No & $\%$ \\
\hline No & 200 & 10 & 5 \\
Yes & 48 & 9 & 19 \\
\hline
\end{tabular}




\section{Discussion}

EXPOSURE

The dust measurements in this study conformed with the British standard for measuring total dust less fly. Unfortunately it was not possible, within the framework of the present study, to measure the respirable fraction.

The dust levels in the Swedish cotton mills were similar to those recently reported in the United States $^{7}$ but were considerably lower than those reported $10-20$ years ago. ${ }^{13}$ The decrease reflects the success of efforts made by the cotton industry to reduce the dust levels. Gram-negative bacteria were found in all the tested baled and carded cotton as well as in the air at all working sites. This agrees with previous investigations. ${ }^{14}$ These bacteria are natural contaminants of different kinds of plants. Ent agglomerans and Pseudomonas sp, such as $P s$ syringae and Ps fluorescens, are common epiphytes on plant surfaces. ${ }^{15}$ Klebsiella are also found on other plant materials. ${ }^{16}$ The air in cotton mills also contains Gram-positive bacteria but these are also found in industries where byssinosis is unknownfor instance, wool mills. ${ }^{5}$ Support for the hypothesis that Gram-negative bacteria are important for inhalation toxicity is obtained from animal experiments. A leukocyte invasion into the airways has been shown after exposure to Gram-negative bacteria whereas exposure to Bacillus subtilis, the most common Gram-positive organism in cotton, causes no such reaction. ${ }^{17}$ Bacterial counts in the present study were considerably higher than in previous investigations on airborne Gram-negative bacteria in cotton mills. ${ }^{56}$ This discrepancy is due to differences in the size distribution of particles containing viable bacteria that affect the number of cfu on agar plates. ${ }^{18}$

\section{REACTIONS}

Symptoms of byssinosis were reported by $19 \%$ of the workers in the investigated cotton mills, but the symptoms were mild -all cases being grade $1 / 2 .{ }^{13}$ A prevalence study of this type is open to the criticism that some employees who have developed symptoms may have left their jobs, as reported by Martin and Higgins. ${ }^{19}$ We were unable to determine how many workers had left for this reason. Because the number of employees at some of the working sites was small, the present data cannot be used to draw accurate dose-response relationships. Nevertheless, they suggested a positive correlation between prevalence of byssinosis and levels of contamination with both dust and viable Gramnegative bacteria at the time when the measurements were made.
Based on an extensive study using the vertical elutriator to measure dust levels in cotton mills in North Carolina, Merchant et al ${ }^{20}$ suggested a doseresponse relationship between the extent of byssinosis and dust levels. They concluded that, even at low dust levels, a certain percentage of the exposed workers would have symptoms of byssinosis. It is generally agreed that the causative agent of byssinosis is not the cotton fibre itself but a contaminant bound to the trash and particularly to the bract. ${ }^{1}$ Dose-response relationships between dust and byssinosis are therefore provisional until the causative agent has been defined.

A relation between the number of Gram-negative bacteria and the extent of byssinosis has earlier been reported by Cinkotai $e t a^{5}$ and by Cinkotai and Whitaker. ${ }^{6} \mathrm{~A}$ relation has also been shown between the magnitude of FEV $_{1}$ changes over the Monday shift and the number of Gram-negative bacteria in the bale cotton used in the different mills. ${ }^{7}$ When the dust level in the present study was related to the extent of byssinosis, exclusion of the area for medical cotton production improved the relation. At this site no workers reported symptoms of byssinosis, although the dust level was high. The number of airborne Gram-negative bacteria was low, and the site falls within the general dose-response relation for bacteria. El-Batawi and El-Din Shash ${ }^{21}$ also reported a low extent of byssinosis in a mill producing medical cotton with relatively high dust levels. Unfortunately, no measurements of airborne bacteria were made in that study.

Earlier investigators have reported a higher prevalence of byssinosis in men than in women..$^{192}$ The same difference was found in the present study and was not caused by smoking or duration of employment. Since the types of work done by men and women may vary from mill to mill, future analysis of this problem should consider each individual's precise working conditions, as well as working history, before any definite conclusions can be drawn.

The relation between duration of employment and appearance of symptoms has been analysed by several authors. Fox et $\mathbf{a l}^{\mathbf{2 3}}$ found that the proportion of employees with byssinotic symptoms increased up to 20 years of employment. Other authors have shown a correlation between the duration of employment and the presence of symptoms among men. ${ }^{819}$ Contrary to this, a study from Finland ${ }^{22}$ did not show a relation between the duration of employment and the distribution of symptoms among the workers. In the present study the prevalence of byssinosis was not related to the duration of employment when age was controlled. Certain workers reported the presence of symptoms after only a few years' 
exposure. In this respect byssinosis differs from several other types of occupational disease where the risk gradually increases with increasing duration of employment. The absence of an association between byssinosis and smoking habits is not in agreement with observations in some other studies. ${ }^{313} \mathrm{~A}$ possible explanation is that both the dust level and the number of cigarettes smoked by the population studied here were lower than in other investigations. The threshold for a potentiating effect may thus not have been reached. Among the non-smokers, a significantly higher percentage of those who had ceased smoking reported symptoms of byssinosis. Conceivably this group contains people who gave up smoking when symptoms of byssinosis appeared.

In conclusion, this study showed that about $20 \%$ of the employees in Swedish cotton mills, which now have low dust levels, had modest symptoms of byssinosis. The distribution of byssinotic symptoms was related to dust levels and also to the number of airborne Gram-negative bacteria.

The study was planned in collaboration with representatives from unions and safety committees in the various mills. It was supported by grants from the Swedish Work Environment Fund and Cotton Inc, Raleigh, USA. The statistical analyses were performed by Anders Odén, PhD.

\section{References}

${ }^{1}$ US Department of Health, Education and Welfare. Occupational exposure to cotton dust. Washington: USDEHW, 1974:1-159. (Publication No (NIOSH) 75-118.)

${ }^{2}$ Schilling RSF, Hughes JPW, Dingwall-Fordyce I, Gilson JC. An epidemiological study of byssinosis among Lancashire cotton workers. $\mathrm{Br} J$ Ind Med 1955;12: 217-27.

${ }^{3}$ Merchant JA, Lumsden JC, Kilburn $\mathrm{KH}$, et al. An industrial study of the biological effects of cotton dust and cigarette smoke exposure. J Occup Med 1973;15: 212-21.

- Pernis B, Vigliani EC, Cavagna C, Finulli M. The role of bacterial endotoxin in occupational disease caused by inhaling vegetable dust. $B r J$ Ind Med 1961;18:120-9.

${ }^{5}$ Cinkotai FF, Lockwood MG, Rylander R. Airborne micro-organisms and prevalence of byssinotic symptoms in cotton mills. Am Ind Hyg Assoc $J$ 1977;38:554-9.

- Cinkotai FF, Whitaker CJ. Airborne micro-organisms and prevalence of byssinotic symptoms in 21 cotton spinning mills in Lancashire. Ann Occup Hyg 1978;21: 239-50.

' Rylander R, Imbus HR, Suh MW. Bacterial contamination of cotton as an indicator of respiratory effects among cardroom workers. $\mathrm{Br} J$ Ind Med 1979;36: 299-304.

${ }^{8}$ Imbus HR, Suh MW. Byssinosis-a study of 10133 textile workers. Arch Environ Health 1973;26:183-91.

${ }^{9}$ Belin L, Bouhuys A, Hoekstra W, Johansson M-B, Lindell S-E, Pool J. Byssinosis in cardroom workers in Swedish cotton mills. Br J Ind Med 1965;22:101-8.

10 Andersen AA. New sampler for the collection sizing and enumeration of viable airborne particles. $J$ Bacteriol $1958 ; 76: 471-84$

${ }^{11}$ Hugh R, Leifson E. The taxonomic significance of fermentative versus oxidative metabolism of carbohydrates by various Gram-negative bacteria. J Bacteriol 1953;66: 24-6.

12 Mantel N. Chi-square tests with one degree of freedom: extensions of the Mantel-Haenszel procedure. Journal of the American Statistical Association 1963;58:690-700.

${ }^{13}$ Schilling RSF, Vigliani EC, Lammers B, Valic F, Gilscn JC. A report on a conference on byssinosis. Excerpta Medica Interna Congress Series 1963;62:137-45.

14 Rylander $R$, Lundholm M. Bacterial contamination of cotton and cotton dust and effects on the lung. $\mathrm{Br} J$ Ind Med 1978;35:204-7.

${ }^{15}$ Dickinson CH, Preece TF. Microbiology of aerial plant surfaces. London: Academic Press, 1976.

16 Duncan DW, Razell WE. Klebsiella biotypes among coliforms isolated from forest environments and farm product. Applied Microbiology 1972;24:933-8.

17 Rylander R, Snella M-C, Garcia I. Pulmonary cell response patterns after exposure to airborne bacteria. Scand J Respir Dis 1975;56:195-200.

${ }^{18}$ Lundholm M, Rylander $R$. Particle size and bacteria content in airborne cotton dust. Wakelyn PJ, ed. Third special session on cotton dust research. Beltwide Cotton Production Research Conference, Phoenix, Arizona, Jan 9-10. Proceedings of the National Cotton Council Publication, 1979:11-12.

19 Martin CF, Higgins JE. Byssinosis and other respiratory ailments. A survey of 6631 cotton textile employees. J Occup Med 1976;18:455-62.

${ }^{20}$ Merchant JA, Lumsden JC, Kilburn $\mathrm{KH}$, et al. Dose response studies in cotton textile workers. $J$ Occup $\mathrm{Med}$ $1973 ; 15: 222-30$.

${ }^{21}$ El-Batawi M, El-Din Shash S. An epidemiological study on aetiological factors in byssinosis. Archiv für Gewerbepathologie und Gewerbehygiene 1962;19:393-402.

${ }^{22}$ Häkkinen I. Byssinosis in cotton industries in Finland. Helsinki: Institute of Occupational Health, 1975:1-83. (In Finnish.)

${ }^{23}$ Fox AJ, Tombleson JBL, Watt A, Wilkie AG. A survey of respiratory disease in cotton operatives. I Symptoms and ventilation test results. Br J Ind Med 1973;30:42-7. 